\title{
PENGEMBANGAN PERANGKAT PEMBELAJARAN FISIKA BERORIENTASI MODEL PEMBELAJARAN KOOPERATIF THINK PAIR SQUARE DALAM MENINGKATKAN KETERAMPILAN SOSIAL DAN KETUNTASAN BELAJAR SISWA
}

\author{
Berry Frisky Apriliyani' ${ }^{1)}$, Wasis ${ }^{2)}$, Z.A Imam Supardi ${ }^{3)}$ \\ ${ }^{1)}$ Mahasiswa Program Studi Pendidikan Sains, Program Pascasarjana Universitas Negeri Surabaya \\ ${ }^{2), 3)}$ Dosen Pascasarjana Prodi Pendidikan Sains Univesrtitas Negeri Surabaya \\ E-mail: berryabrisam2014@gmail.com
}

\begin{abstract}
This study aimed to describe feasibility of Physics learning materials developed oriented cooperative learning model of think pair square type to improve social skills and master of learning outcomes in the learning of heat in senior high school (SMA). Development is done based on the model of four-D. Learning materials developed consists of lesson plans, Student Textbook, worksheets, achievement test and observation of social skills of students. The learning materials is tryout to the class X SMA Kemala Bhayangkari I Surabaya in the second semester of the school year 2013/2014. The replication consist of three classes namely X-A class, X-B class and X-C .One group pretest and postest design are used in the experiment. Descriptive technique is used in data analysis. From data analysis of three classes replication show that the validation of learning material is included to good category, the application of learning material is also good, learning activity close to students centered and students' respont learning acivity is postitive. Learning outcomes of X-A class, X-B class and X-C class is average 82 with, medium category in normally gain score. The outcomes of students sosial skills in X-A class, X-B class and X-C class is 2.80 included to good category. Based on the data analysis it can be concluded that the Physics Learning Materials Oriented Cooperative Learning Model of Think Pair Square Type for Improving Students Social Skills and Student Learning Master feasible to be used in learning activity.
\end{abstract}

Key words: Cooperative Learning of Think Pair Square Type, Social Skills, and Mastery of Learning Outcomes

\begin{abstract}
Abstrak: Penelitian ini ditujukan untuk mendeskripsikan kelayakan perangkat pembelajaran Fisika berorientasi pembelajaran kooperatif Think Pair Square untuk meningkatkan keterampilan sosial dan ketuntasan hasil belajar pada materi Kalor di SMA. Pengembangan perangkat pembelajaran dilakukan berdasarkan model four-D tetapi hanya sampai tahap pengembangan (develop). Perangkat pembelajaran yang dikembangkan terdiri dari RPP, Buku Ajar Siswa, LKS, tes hasil belajar dan pengamatan keterampilan sosial siswa. Perangkat pembelajaran tersebut diujikan terhadap siswa kelas X SMA Kemala Bhayangkari I Surabaya pada semester ganjil tahun ajaran 2014/2015 dengan replikasi 3 kelas yaitu kelas X-A, kelas X-B dan kelas X-C. Rancangan yang digunakan pada penelitian adalah one group pre-test dan post-test design. Data hasil penelitian dianalisis secara deskriptif kualitatif. Hasil penelitian secara keseluruhan untuk 3 kelas replikasi menunjukkan bahwa validitas perangkat pembelajaran yang dikembangkan berkategori baik, keterlaksanaan RPP berkategori baik, aktivitas siswa mengalami peningkatan kearah yang berpusat pada siswa, siswa memberikan respon positif terhadap proses pembelajaran. Hasil belajar kelas $\mathrm{X}-\mathrm{A}$, kelas X-B dan kelas X-C rata-rata sebesar 82 dengan dengan skor peningkatan (normal-gain) sedang,. Keterampilan sosial siswa kelas X-A, kelas X-B dan kelas X-C rata-rata sebesar 2.80 dengan kategori mengalami kemajuan. Berdasarkan hasil analisis data dapat disimpulkan bahwa perangkat pembelajaran Fisika Berorientasi Model Pembelajaraan Kooperatif Tipe Think Pair Square dalam Meningkatkan Keterampilan Sosial Siswa dan Ketuntasan Belajar Siswa layak digunakan dalam pembelajaran.
\end{abstract}

Kata kunci: Pembelajaran Kooperatif tipe Think Pair Square, Keterampilan Sosial dan Ketuntasan Hasil Belajar.

\section{PENDAHULUAN}

Bangsa Indonesia masih dihadapkan pada permasalahan multidimensi yang menyentuh berbagai tatanan kehidupan mendasar manusia sampai saat ini. Bukan hanya berkaitan dengan aspek ekonomi, namun juga aspek sosial, budaya dan akhlak. Krisis pada aspek sosial khususnya sudah sampai pada bentuk yang cukup memprihatinkan. Beberapa perilaku sosial siswa dan mahasiswa kita, bahkan orang dewasa sangat memprihatinkan seperti perilaku-perilaku kekerasan, pemaksaan kehendak, pengrusakan, konflik antar kelompok serta tawuran. Sesungguhnya dalam menghadapi kondisi yang demikian, pendidikan dapat memberikan kontribusi yang cukup besar.

Pendidikan pada hakekatnya usaha sadar untuk menyiapkan peserta didik melalui kegiatan bimbingan, 
pengajaran dan atau latihan bagi peranannya di masa yang akan datang yang semakin rumit, cepat berubah dan sulit diprediksi. Keadaan ini membawa dampak persaingan yang sangat ketat untuk mendapatkan hidup yang layak, dimana mereka yang lebih kompetitiflah yang dapat bertahan dan mendapatkan kemudahan. Untuk menghadapi persaingan ini, pendidikan diharapkan mampu membekali peserta didik dengan berbagai kemampuan handal yang dapat dipergunakan sebagai pegangan untuk kehidupan yang lebih baik.

Peraturan Pemerintah No 69 Tahun 2013 tentang sistem Pendidikan Nasional, Kurikulum 2013 bertujuan untuk mempersiapkan manusia Indonesia agar memiliki kemampuan hidup sebagai pribadi dan warga negara yang beriman, produktif, kreatif, inovatif, dan afektif serta mampu berkontribusi pada kehidupan bermasyarakat, berbangsa, bernegara, dan peradaban dunia (Amri, 2013).

Pendidikan yang baik tidak semata-mata bertujuan mengasah kecerdasaan peserta didik saja, tetapi hendaknya juga ikut meningkatkan kemampuan/keterampilan berpikir (thinking skills), mengubah pembentukan karakter (character building), watak, kepribadian dan keterampilan sosial siswa agar menjadi lebih baik, sopan dalam tataran etika maupun estetika. Oleh Karena itu faktor keterampilan berpikir, perilaku karakter dan keterampilan sosial sangat penting untuk membekali siswa dalam kehidupan sehari-hari. Pendidikan karakter merupakan upaya yang harus melibatkan semua pihak baik rumah tangga dan keluarga, sekolah, dan lingkungan sekolah serta lingkungan masyarakat (Simamora, 2011).

Pada kalangan siswa sekolah dasar dan menengah, seperti juga masyarakat pada umumnya gejala masalah pribadi dan sosial ini juga tampak dalam perilaku keseharian. Sikap-sikap individualistis, egoistis, acuh tak acuh, kurangnya rasa tanggung jawab, malas berkomunikasi dan berinteraksi atau rendahnya empati merupakan fenomena yang menunjukkan adanya kehampaan nilai sosial dalam kehidupan sehari-hari (Hairida, 2013).

Permasalahan lain berdasarkan wawancara dan pengamatan dalam proses pembelajaran IPA-Fisika di SMA Kemala Bhayangkari terungkap bahwa pembelajaran yang dilakukan oleh guru masih bersifat teacher centered (terpusat pada guru); masih banyaknya siswa yang membuat PR dengan cara menyontek; kurangnya insiatif siswa untuk bertanya kepada guru; masih banyak yang kurang teliti dalam mengerjakan tugas; kecenderungan siswa hanya menerima materi yang diajarkan, tanpa mau menelaah lebih dalam dan berkelanjutan; apabila ditanya guru, tidak ada yang mau menjawab tetapi mereka menjawab bersamaan sehingga suaranya tidak jelas; masih terdapat siswa yang suka menertawakan temannya jika disuruh ke depan kelas; saat mengerjakan latihan yang terdapat dalam buku sumber, masih terdapat siswa yang mengerjakannya dengan menebak saja tanpa mau membacanya terlebih dahulu; jika ditanya contoh dalam kehidupan seharihari, maka siswa akan memberikan jawabannya sesuai dengan yang diberikan guru; masih adanya siswa yang mengerjakan tugas secara asal-asalan; kemampuan guru dalam merancang dan melaksanakan pembelajaran yang menantang masih kurang; dan pembelajaran yang dilaksanakan kurang bermakna dibuktikan dengan ketidaksiapan dalam kuis di akhir pembelajaran (Husna, 2012).

Berdasarkan pengamatan terhadap proses pembelajaran IPA Fisika, dapat disimpulkan bahwa perilaku berkarakter atau keterampilan sosial siswa masih rendah. Melihat kondisi yang demikian, perlu adanya model pembelajaran yang bisa mengatasi masalah pendidikan yang telah diungkapkan di atas, terutama yang dapat meningkatkan kemampuan memecahkan masalah dengan keterampilan berpikir,

melatihkan karakter serta keterampilan sosial siswa. Model pembelajaran yang dimaksud harus memiliki syarat antara lain: dapat membuat siswa mampu mengkonstruksi pengetahuan, membuat siswa mandiri dalam belajar, meningkatkan interaksi siswa, melatih siswa untuk mengkomunikasikan idenya serta meningkatkan pengetahuan siswa memecahkan masalah. Dengan ciri-ciri yang dimiliki tersebut diharapkan model pembelajaran itu akan berakibat pada peningkatan hasil belajar serta keterampilan karakter/sosial siswa.

Penelitian yang telah dilakukan oleh Nurhayati Nufus (2012) di SMP Negeri 1 Sangatta Utara menunjukkan bahwa perangkat pembelajaran dengan menggunakan model kooperatif Think Pair Share pada materi bunyi yang dikembangkan layak dan valid serta mampu untuk melatihkan keterampilan proses sains siswa kelas VIII di sekolah tersebut namun belum terlihat dengan baik dalam melatihkan keterampilan sosial pada siswa.

Cooperatif Learning merupakan suatu model pembelajaran yang saat ini banyak digunakan untuk mewujudkan kagiatan belajar yang berpusat pada siswa (student oriented), mengembangkan keterampilan berpikir, meningkatkan perilaku berkarakter serta keterampilan sosial tertutama untuk mengatasi permasalahan yang ditemukan guru dalam mengaktifkan siswa, yang tidak dapat bekerja sama dengan orang lain, siswa yang agresif dan tidak peduli pada orang lain. Model pembelajaran kooperatif merupakan teknik-teknik kelas praktis yang dapat digunakan guru setiap hari untuk membantu siswa belajar setiap mata pelajaran, mulai dari keterampilanketerampilan dasar sampai pemecahan masalah yang kompleks (Nur, 2011). 
Materi kalor merupakan pokok bahasan yang diajarkan pada siswa SMA kelas X semester II (genap). Kompetensi dasar dari materi ini adalah menganalisis pengaruh kalor dan perpindahan kalor pada kehidupan sehari-hari. Pokok bahasan tersebut memiliki banyak informasi tentang fakta-fakta dalam kehidupan seharihari, sehingga menarik dalam proses pembelajaran. Mempelajari materi tersebut dibutuhkan model pembelajaran yang inovatif, salah satunya adalah dengan pembelajaran kooperatif, yang mempunyai beberapa keunggulan di antaranya siswa lebih banyak belajar dengan temannya, membantu siswa memahami konsep-konsep yang sulit, membantu siswa menumbuhkan kemampuan kerjasama dan jiwa sosial mereka.

Pembelajaran kooperatif di dalamnya terdapat beberapa varian yang dapat diterapkan oleh guru. Salah satu model pembelajaran yang sesuai untuk memperoleh pengetahuan Fisika yang baik dan untuk mengatasi kelemahan dalam proses belajar mengajar adalah model pembelajaran kooperatif tipe Think Pair Square yang merupakan modifikasi dari model pembelajaran Think Pair Share yang dikembangkan oleh Anita Lie, dimana dalam model ini siswa diberikan kesempatan untuk berbagi dengan yang lain, mengajar dan diajar oleh sesama siswa yang menjadi bagian penting dalam proses belajar-mengajar. Melalui model pembelajaran kooperatif tipe berpikir-berpasanganberempat ini diharapkan dapat membuat siswa lebih aktif serta lebih terampil dalam mengembangkan kecakapan/keterampilan berpikir, perilaku karakter dan keterampilan sosial serta menumbuhkan minat serta motivasinya (Lie, 2002).

Menurut peneliti, siswa SMA akan lebih antusias di dalam belajar apabila dihadapkan langsung dengan permasalahan yang dekat dengan keseharian siswa, mengerjakan bersama-sama dengan teman sebayanya sehingga dapat dilatihkan keterampilan sosialnya sejak dini. Oleh karena itulah peneliti tertarik untuk mengadakan penelitian dengan menerapkan model pembelajaran kooperatif Think Pair Square di SMA. Peneliti berharap dengan menerapkan model pembelajaran kooperatif Think Pair Square dapat mendorong keaktifan sosial siswa dalam proses pembelajaran dan meningkatkan hasil belajar, sehingga materi yang diajarkan di kelas lebih mudah dipahami dan dapat digunakan siswa untuk memecahkan masalah yang dihadapi dalam kehidupan sehari-hari.Untuk dapat melaksanakan pembelajaran kooperatif Think Pair Square, maka perlu dikembangkan perangkat pembelajaran kooperatif tipe Think Pair Square yang baik sesuai dengan langkah-langkah dalam model pengembangan perangkat yang sesuai.

Berdasarkan uraian di atas, perlu dilakukan penelitian tentang Pengembangan Perangkat
Pembelajaran Fisika Berorientasi Model Pembelajaran Kooperatif Tipe Think Pair Untuk Meningkatkan Keterampilan Soaial dan Ketuntasan Belajar Siswa. Secara umum, tujuan penelitian ini adalah untuk menghasilkan perangkat pembelajaran fisika model kooperatif tipe think pair sqaure yang valid, praktis, dan efektif untuk melatihkan meningkatkan keterampilan sosial dan ketuntasan belajar siswa

\section{METODE PENELITIAN}

Penelitian ini merupakan penelitian pengembangan. Penelitian ini mengembangkan perangkat pembelajaran fisika SMA dengan model kooperatif tipe Think Pair Sqaure untuk meningkatkan keterampilan sosial dan ketuntasan belajar siswa. Penelitian pengembangan ini mengacu pada model model 4-D dari Thiagiarajan dalam Ibrahim (2002). Tahapan-tahapannya adalah define (pendefinisian), design (perancangan), develop (pengembangan), dan disseminate (penyebaran). Perangkat pembelajaran yang dihasilkan meliputi Rencana Pelaksanaan Pembelajaran (RPP), Lembar Kegiatan Siswa (LKS), buku ajar materi kalor, instrumen penilaian hasil belajar dan instrumen keterampilan sosial siswa.

Subjek penelitian dari penerapan hasil pengembangan perangkat pembelajaran model kooperatif tipe think pair square pada materi kalor pada uji coba adalah siswa kelas X SMA Kemala Bhayangkari I Surabaya tahun pelajaran 2013/2014. Pada uji coba I melibatkan 12 siswa dan uji coba II sebanyak 84 siswa pada 3 kelas. Rancangan uji coba digunakan untuk mengujicobakan hasil pengembangan perangkat pembelajaran fisika model inkuiri terbimbing. Rancangan penelitian menggunakan rancangan one-group pretest-posttest design. Rancangan penelitian ini melibatkan satu kelompok yang diobservasi pada tahap pretest $\left(O_{l}\right)$ yang kemudian dilanjutkan dengan perlakuan tertentu $(X)$ dan posttest $\left(\mathrm{O}_{2}\right)$ (Prabowo,2002).

\section{$\begin{array}{lll}O_{1} & \mathbf{X} & O_{2}\end{array}$}

Dengan:

$O_{l}$ adalah uji awal (pretest) untuk mengetahui penguasaan siswa terhadap materi pelajaran sebelum pembelajaran.

$\mathrm{O}_{2}$ adalah uji awal (posttest) untuk mengetahui penguasaan siswa terhadap materi pelajaran sesudah pembelajaran.

$X$ adalah perlakuan pembelajaran dengan menggunakan perangkat pembelajaran model inkuiri terbimbing.

Langkah-langkah pengembangan perangkat pembelajaran dideskripsikan pada Gambar 1. 


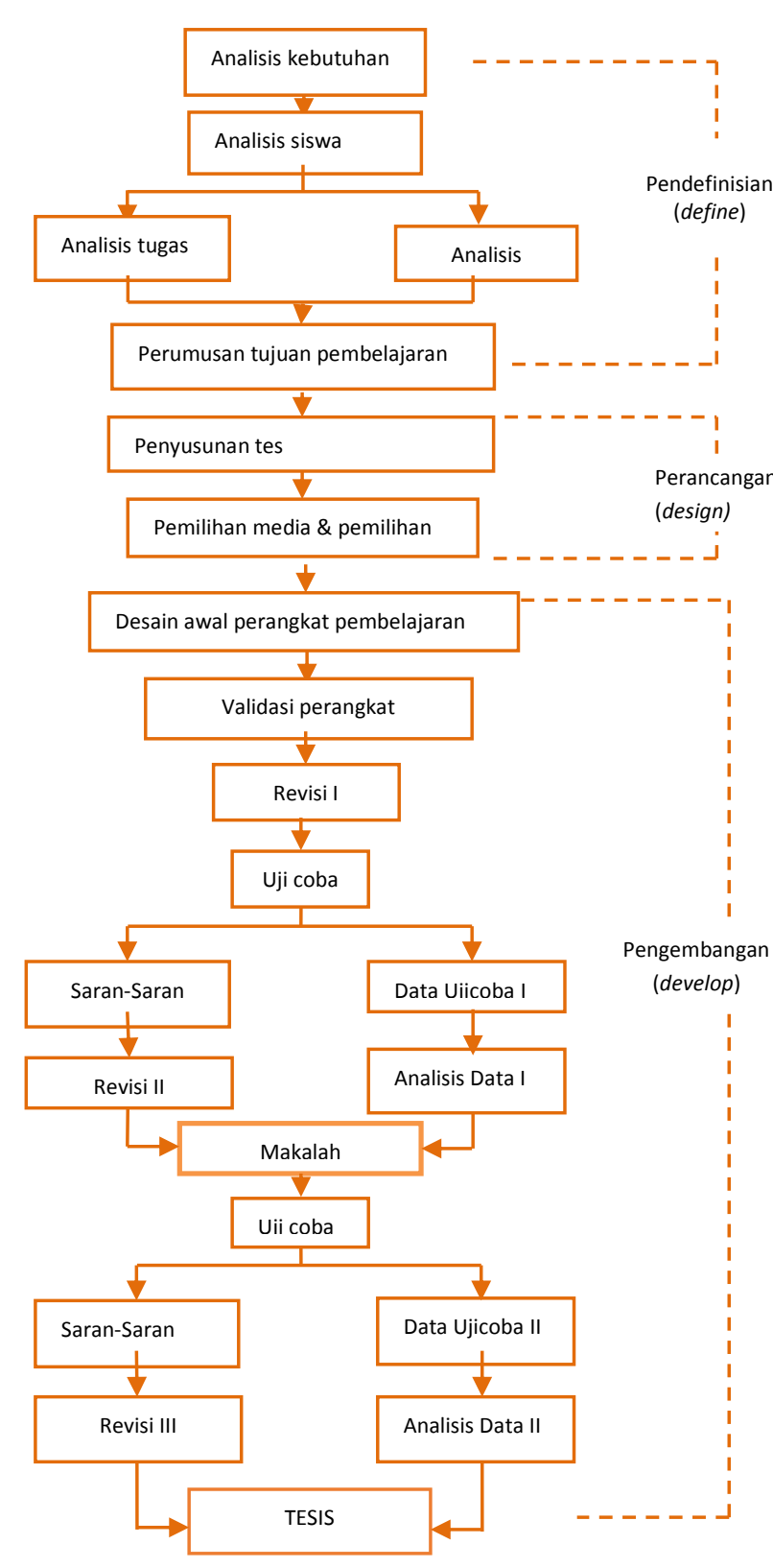

Gambar 3.1. Diagram alir rancangan pengembangan perangkat pembelajaran ( diadaptasi dari Ibrahim, 2002)

Teknik pengumpulan data digunakan untuk memperoleh bahan-bahan yang relevan, akurat, dan dapat digunakan dengan tepat sesuai tujuan penelitian. Teknik pengumpulan data yang digunakan dalam penelitian ini adalah: (1) pengamatan; (2) tes; dan (3) angket.

\section{A. Teknik Analisis Data}

Analisis hasil pengembangan perangkat pembelajaran dan hasil ujicoba perangkat pembelajaran fisika yang menggunakan model pembelajaran kooperatif tipe Think Pair Sqaure dalam penelitian ini adalah sebagai berikut:

\section{Analisis Validitas Perangkat Pembelajaran}

Teknik analisis data validitasi perangkat pembelajaran meliputi RPP, buku ajar, LKS, instrumen tes pengetahuan, intrumen keterampilan sosial siswa menggunakan deskriptif kualitatif. Data yang diperoleh dianalisis dengan rata-rata skor tiap aspek.

2. Analisis Keterlaksanaan Pembelajaran

Teknik analisis data keterlaksanaan pembelajaran menggunakan deskriptif kuantitatif dan kualitatif. Nilai dari keterlaksanaan pembelajaran yang dilakukan oleh dua pengamat yang sudah memahami lembar pengamatan secara benar, kemudian data diolah dengan menghitung dengan menggunakan persamaan sebagai berikut:

$\mathrm{P}=\frac{\text { Jumlah tahap pembela jaran yang dilaksanakan }}{\text { jumlah seluruh tahap pembelajaran }} \times 100 \%$

Pelaksanaan pengamatan masing-masing pengamat memberikan penilaian (4: baik, 3: cukup baik, 2: kurang baik, dan 1: tidak baik). Kriteria penilaian yang diperoleh dengan membandingkan ratarata skala penilaian diberikan kedua pengamat dengan kriteria penilaian di bawah ini:

$$
\begin{array}{ll}
1.00-1.49 & : \text { Tidak baik } \\
1.50-2.49 & : \text { Kurang baik } \\
2.50-3.49 & : \text { Cukup baik } \\
3.50-4.00 & \text { : Baik }
\end{array}
$$

(Ratumanan \& Laurens, 2011)

\section{Analisis Aktivitas Siswa}

Teknik analisis data pengamatan aktivitas siswa menggunakan deskriptif kuantitatif dan kualitatif. untuk memberikan deskripsi aktivitas siswa selama kegiatan pembelajaran dengan model pembelajaran inkuiri terbimbing. Data hasil pengamatan aktivitas siswa selama kegiatan pembelajaran dianalisis dengan menggunakan persentase. Rumus persentase aktivitas siswa dapat disajikan dalam bentuk persamaan berikut.

$$
P=\frac{f_{a}}{f_{b}} \times 100 \%
$$

Keterangan :

$P$ : persentase aktivitas siswa

$f a$ : jumlah frekuensi kategori pengamatan

$f b$ : jumlah frekuensi seluruh kategori pengamatan

(Nufus, 2010)

\section{Analisi Ketuntasan Belajar Siswa}

Data ketuntasan atau ketercapaian pembelajaran siswa dinyatakan dalam persentase.

a) Ketuntasan Individual

$$
\text { Pindividual }
$$

$$
=\left(\frac{\text { jumlah indikator yang dicapai }}{\text { jumlah seluruh indikator }}\right) \times 100 \%
$$


Hasil belajar individual dapat dikatakan tuntas jika memenuhi nilai ketuntasan minimum (KKM) yang telah ditetapkan oleh sekolah yakni 2,66 dengan kategori B- . Kategori ketuntasan belajar seluruh siswa jika 75\% memenuhi nilai KKM

b) Ketuntasan Indikator

Satu tujuan pembelajaran tuntas apabila persentasenya siswa mencapai $(\mathrm{P} \geq 75 \%)$.

$$
\mathrm{P}=\left(\frac{\sum \text { ketercapaian tiap indikator }}{\sum \text { skor indikator dalam KD }}\right) \times 100 \%
$$

c) Sensitivitas Butir Soal

Untuk menghitung sensitivitas butir soal digunakan rumus sebagai berikut :

$$
\mathrm{S}=\frac{R_{A}-R_{B}}{T}=P_{A}-P_{B}
$$

Keterangan :

$$
\begin{aligned}
\mathrm{S}= & \text { Sensitivitas butir soal } \\
\mathrm{R}_{\mathrm{A}}= & \text { Jumlah siswa yang menjawab benar pada } \\
& \text { uji akhir }\left(\mathrm{U}_{2}\right) \\
\mathrm{R}_{\mathrm{B}}= & \text { Jumlah siswa yang menjawab benar pada } \\
& \text { uji awal }\left(\mathrm{U}_{1}\right) \\
\mathrm{T}= & \text { Jumlah siswa yang mengkuti tes } \\
\mathrm{P}_{\mathrm{A}}= & \text { Proporsi jawaban benar } \\
\mathrm{P}_{\mathrm{B}}= & \text { Proporsi jawaban benar uji awal }
\end{aligned}
$$

(Gronlund,1985)

Butir soal memiliki sensitivitas $\geq 0,30$ memiliki kepekaan yang cukup terhadap efek-efek pembelajaran. Nilai positif yang semakin besar menunjukkan kepekaan butir soal terhadap pembelajaran juga semakin besar. (Aiken 1997).

\section{Analisis Keterampilan Sosial Siswa}

Analisis data keterampilan sosial siswa dilakukan secara statistik deskriftif yaitu dengan menvisualisasikan data persentase keterampilan sosial siswa dalam bentuk diagram batang.

Penguasaan keterampilan sosial dipresentasikan dengan menggunakan rumus sebagi berikut :

$$
P=\frac{f_{a}}{f_{b}} \times 100 \%
$$

Keterangan :

$$
\begin{aligned}
P & : \text { Persentase aktivitas siswa } \\
f a & : \text { Jumlah frekuensi rata-rat keterampilan yang } \\
& \text { muncul } \\
f b & : \text { Jumlah frekuensi seluruh keterampilan } \\
& \text { yang diamati }
\end{aligned}
$$

(Nufus, 2010).

Pelaksanaan pengamatan masing-masing pengamat memberikan penilaian (4: sangat memuaskan,
3: memuaskan, 2: mengalami kemajuan, dan 1: memerlukan perbaikan). Kriteria penilaian yang diperoleh dengan membandingkan rata-rata skala penilaian diberikan kedua pengamat dengan kriteria penilaian di bawah ini:

$$
\begin{array}{ll}
\mathrm{D}=1.00-1.99 & : \text { memerlukan perbaikan } \\
\mathrm{C}=2.00-2.99 & : \text { mengalami kemajuan } \\
\mathrm{B}=3.00-3.99 & : \text { memuaskan } \\
\mathrm{A}=4.00 & \text { : sangat memuaskan }
\end{array}
$$

$N$-gain menunjukkan peningkatan kemampuan multi representasi fisika siswa sebelum dan setelah perlakuan.

$$
\langle g\rangle=\frac{\text { Spost }- \text { Spre }}{\text { S max }- \text { Spre }}
$$

Dengan:

$$
\begin{array}{ll}
\langle g\rangle & \text { : Nilai gain } \\
\text { Spost } & \text { : Nilai posttest } \\
\text { Spre } & \text { : Nilai pretest } \\
\text { Smax } & \text { : Nilai maksimal }
\end{array}
$$

Selanjutnya dari hasil perhitungan $n$-gain tersebut kemudian dikonversi dengan kriteria sebagai berikut:

Tabel 1. Kriteria normalized gain

\begin{tabular}{|l|l|}
\hline \multicolumn{1}{|c|}{ Skor $N$-Gain } & \multicolumn{1}{c|}{ Kriteria Normalized Gain } \\
\hline $0.70<N$-Gain & Tinggi \\
\hline $0.30 \leq N$-Gain $\leq 0.70$ & Sedang \\
\hline$N$-Gain $<0.30$ & Rendah \\
\hline
\end{tabular}

(Hake, 1999)

\section{1) Analisis untuk Data Respon Siswa}

Data tentang respon siswa diperoleh dari angket respon siswa terhadap kegiatan pembelajaran, dan selanjutnya dianalisis dengan menggunakan deskriptif kualitatif. Data respon yang diperoleh digunakan menindaklanjuti kegiatan pembelajaran dengan menggunakan model inkuiri terbimbing. Respon siswa pada pembelajaran ini berkategori positif apabaila $>70 \%$ siswa menyatakan tertarik pada pembelajaran dan komponen-komponen pembelajaran di dalamnya. Secara matematis dapat ditulis sebagai berikut:

Keterangan:

$$
P=\frac{\sum K}{\sum N} \times 100 \%
$$

$$
\begin{aligned}
& P \quad: \text { Persentase skor respon siswa } \\
& \sum K: \text { Jumlah siswa yang memilih jawaban Ya } \\
& \quad \text { atau Tidak } \\
& \sum N: \text { Jumlah siswa yang mengisi angket }
\end{aligned}
$$

\section{HASIL PENELITIAN DAN DISKUSI}

\section{A. Hasil Pengembangan Perangkat Pembelajaran}

Hasil pengembangan perangkat pembelajaran fisika model kooperatif tipe Think Pair Square yang dikembangkan valid untuk digunakan dalam pembelajaran fisika untuk meningkatkan keterampilan 
sosial dan ketuntasan hail belajar siswa.

1. Hasil Validasi Perangkat Pembelajaran

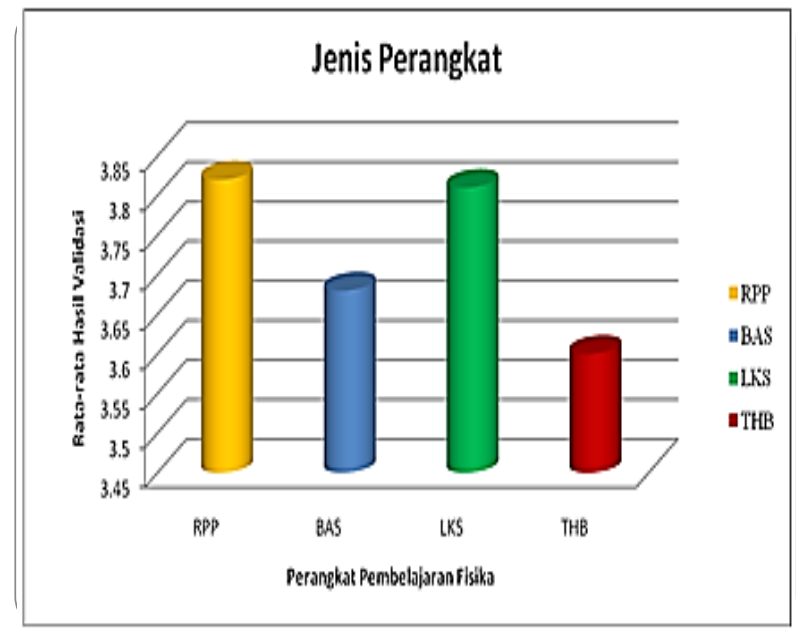

Gambar 2. Hasil validasi pengembangan perangkat pembelajaran fisika

2. Keterbacaan Buku Ajar

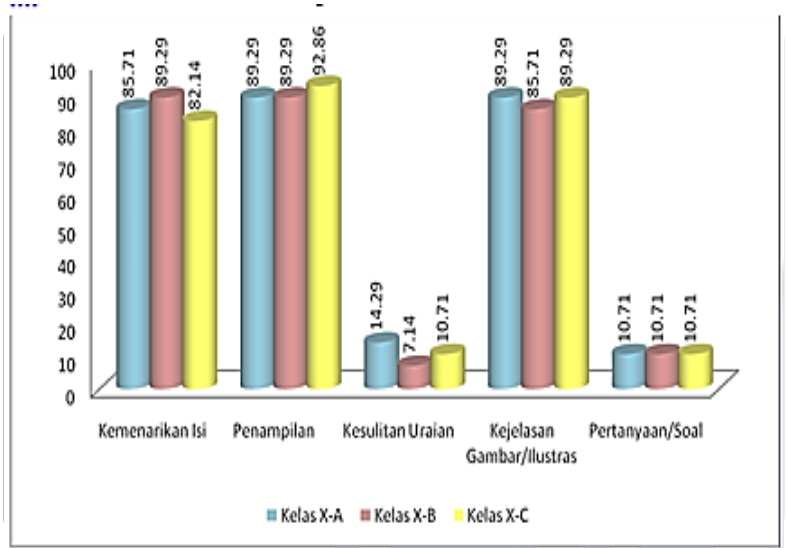

Gambar 3. Keterbacaan BAS

c) Keterbacaan LKS

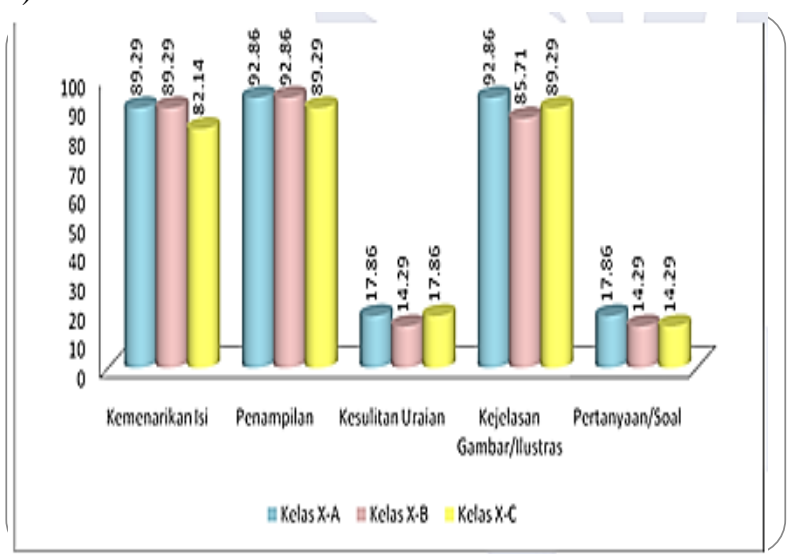

Gambar 4. Keterbacaan LKS

Semua keterbacaan BAS dan LKS mendapatkan respon yang positif.

\section{B. Kepraktisan Perangkat Pembelajaran \\ 1. Keterlaksanaan RPP}

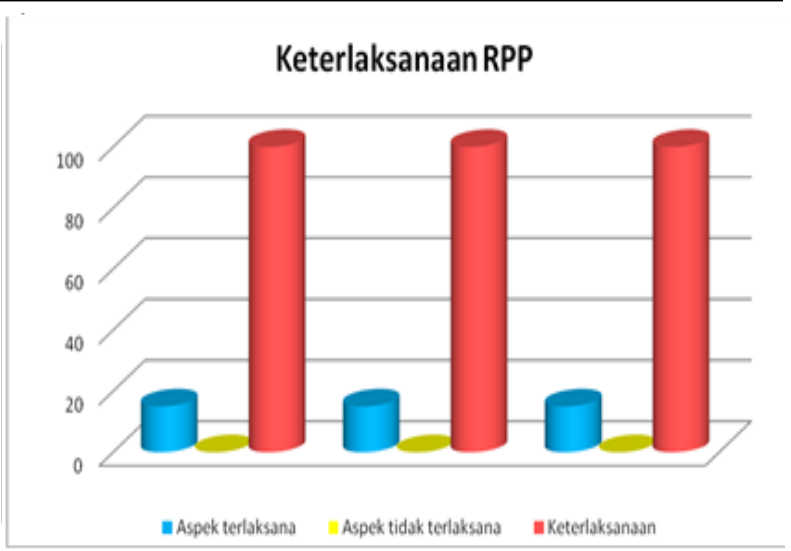

Gambar 5. Keterlaksanaan RPP di kelas X-A,Kelas XB dan Kelas X-C

Tabel 1. Keterlaksanaan RPP

\begin{tabular}{|c|c|c|c|c|}
\hline \multirow[t]{2}{*}{ No } & \multirow{2}{*}{$\begin{array}{l}\text { Aspek yang } \\
\text { Diamati }\end{array}$} & \multicolumn{3}{|c|}{$\begin{array}{l}\text { Rata-rata Seluruh } \\
\text { Pertemuan }\end{array}$} \\
\hline & & X-A & X-B & $\mathrm{X}-\mathrm{C}$ \\
\hline I & Pendahuluan & 3.61 & 3.83 & 3.89 \\
\hline II & Kegiatan Inti & 3.73 & 3.78 & 3.82 \\
\hline III & Penutup & 3.50 & 3.67 & 3.50 \\
\hline IV & Suasana Kelas & 3.94 & 3.89 & 4.00 \\
\hline \multicolumn{2}{|c|}{ Rata-rata Kelas } & 3.70 & 3.79 & 3.80 \\
\hline
\end{tabular}

Keterlaksanaan Rencana Pelaksanaan Pembelajaran (RPP) dapat dilihat dari hasil penilaian keterlaksanaan yang diberikan dua pengamat. Pengamatan terhadap keterlaksanaan pembelajaran bertujuan untuk mengetahui keberhasilan guru dalam menerapkan tahap-tahap dalam pembelajaran yang direncanakan sehingga dapat diukur efektivitasnya pada akhir pembelajaran. Pengamatan terhadap kegiatan belajar mengajar pada tahap pendahuluan, guru memulai pembelajaran dengan berdoa, memotivasi siswa dengan menyajikan fenomena, serta mengkomunikasikan tujuan pembelajaran. Dalam hal ini, guru memotivasi siswa untuk berkonsentrasi pada kegiatan belajar mengajar dengan menyampaikan tujuan-tujuan pembelajaran dan memberikan gambaran fenomena dalam kehidupan sehari-hari sehingga muncul rasa ingin tahu siswa, yang dapat terlihat dari hasil pengamatan keterlaksanaan pembelajaran pada tiap RPP berkategori baik.

Pada tahap kegiatan inti, dimana guru menyampaikan informasi singkat tentang materi yang dipelajari, membagi siswa menjadi kelompok berpasangan berempat, membagi buku dan LKS, serta melatihkan siswa dalam sintaks pembelajaraan kooperatif Think Pair Square dimana di dalamnya terdapat kegiatan keterampilan sosial yang harus dilaksanakan oleh siswa, yakni pada saat diskusi kelompok dan presentasi kelompok menunjukkan ratarata keterlaksanaan pembelajaran dengan kategori baik 
sesuai dengan pendapat Arends (2008) bahwa pembelajaran kooperatif adalah memberikan kesempatan kepada siswa untuk mengemukakan ide dan bekerjasama secara interdependen pada tugas yang sama serta melalui penggunaan struktur reward kooperatif, belajar saling menghargai.

Pada bagian penutup, membimbing siswa membuat kesimpulan, menugasi siswa mengerjakan soal-soal yang disediakan sebagai pekerjaan rumah menunjukkan rata-rata keterlaksanaan baik. Berdasarkan suasana kelas selama KBM berjalan dengan sesuai sintaks dan tujuan pembelajaran yang diharapkan, selama KBM cenderung berpusat pada siswa, dimana setiap fase di dalam pembelajarannya diorganisir sedemikian rupa sehingga siswa dapat menguasai kompetensi-kompetensi yang harus dicapai dengan jalan berperan aktif, senada dengan Teori Zone of proximal development oleh Vygotsky mengemukakan bahwa proses pembelajaran akan terjadi jika siswa bekerja atau menangani tugas-tugas yang belum dipelajari, akan tetapi tugas-tugas tersebut masih dalam jangkauan siswa tersebut. Zona perkembangan terdekat adalah tingkat perkembangan sedikit di atas daerah perkembangan siswa saat ini. Aspek-aspek yang diamati dalam RPP meliputi kegiatan pendahulan, kegiatan inti, penutup serta suasana kelas yang diajarkan oleh guru. Rata-rata hasil pengamatan keterlaksanaan pembelajaran secara keseluruhan yang dilakukan oleh pengamat pada suasana kelas termasuk dalam kategori baik.

Berdasarkan hasil pengamatan terhadap keterlaksanaan Rencana Pelaksanaan Pembelajaran (RPP) dapat disimpulkan bahwa langkah-langkah dalam RPP terlaksana dengan baik di kelas X-A, kelas X-B dan kelas $\mathrm{X}-\mathrm{C}$ karena skor rata-rata yang diberikan pengamat berturut-turut sebesar $3.70,3.79$, dan 3.80 . Hal ini menandakan bahwa RPP yang telah dibuat dapat terlaksana dengan baik. Sementara itu instrumen pengamatan keterlaksanaan RPP tergolong reliabel karena reliabilitasnya lebih besar dari $75 \%$ berturutturut yakni pada kelas X-A diperoleh nilai sebesar 98,41\%, di kelas X-B sebesar $98.64 \%$ dan di kelas X-C sebesar 99.09\%. Menurut Borich (1994) kriteria reliabilitas instrumen dikatakan baik apabila koefisien reliabilitasnya $\geq 0,75$ atau $75 \%$. Secara umum sintaks pembelajaran dengan menggunakan model ini dapat dilaksanakan oleh guru sehingga perangkat pembelajaran yang dikembangkan memberikan kemudahan bagi guru dalam melaksanakan pembelajaran dan memberikan kemudahan bagi siswa untuk berhasil menyelesaikan pembelajaran dan meningkatkan keterampilan sosialnya.

Aktivitas siswa dalam pembelajaran ini adalah rangkaian kegiatan yang dilakukan siswa selama mengikuti pembelajaran kooperatif tipe Think Pair
Square untuk meningkatkan keterampilan sosial dan ketuntasan hasil belajar siswa.Aktivitas siswa diamati selama kegiatan pembelajaran berlangsung menggunakan instrumen lembar pengamatan aktivitas siswa. Aktivitas siswa kelas X-A, kelas X-B dan Kelas $\mathrm{X}-\mathrm{C}$ selama mengikuti pembelajaran dikategorikan baik. Hal ini menunujukkan bahwa aktivitas pembelajaran telah menceminkan aktivitas yang sesuai dengan tahap-tahap pembelajaran kooperatif tipe Think Pair Square. Dalam pembelajaran Fisika berorientasi model pembelajaran kooperatif Think Pair Square ini aktivitas yang menunjukkan keterlibatan aktif siswa meliputi melakukan percobaan, bekerjasama melakukan percobaan, berdiskusi, bertanya dan menangapi pertanyaan, serta menyimpulkan. Sementara itu aktivitas yang berupa mendengarkan/memperhatikan penjelasan guru tidak menunjukkan keterlibatan aktif siswa selama KBM.

Proses kegiatan pembelajaran, pada menit awal guru melakukan penjelasan konsep yang akan diajarkan dan memberi contoh masalah otentik dalam kehidupan sehari-hari, aktivitas siswa yang dilakukan adalah mendengarkan dan memperhatikan penjelasan guru, mencatat, dan menjawab pertanyaan dari guru seputar masalah otentik yang dikemukakan guru sebelumnya. Kemudian pada kegiatan inti siswa mulai melakukan aktivitas berlatih keterampilan proses melalui kegiatan eksperimen, siswa dalam kelompok berpasangan berempatnya melakukan diskusi antar pasangannya atau bertanya kepada guru serta saling bekerjasama dalam kelompok berempatnya yang telah ditentukan untuk menyelesaikan soal-soal yang ada pada LKS yang terkait dengan penguasan konsep/pengetahuan dan saling menghormati pendapat teman. Hal ini sesuai dengan hasil penelitian Nufus (2012) yang menyatakan bahwa sikap atau aktivitas siswa dalam kegiatan pembelajaran dengan pembelajaran kooperatif Think Pair Share sangat dipengaruhi oleh aktivitas guru dan metode yang digunakan dalam pembelajaran.

Berdasarkan hasil analisis pengamatan aktivitas siswa diperoleh reliabilitas aktivitas siswa pada tiap-tiap kelas replikasi yakni kelas X-A sebesar $96.71 \%$, kelas X-B sebesar $97.66 \%$ dan kelas X-C sebesar $97.85 \%$. Data tersebut menunjukkan bahwa aktivitas siswa untuk tiap kelas tidak jauh berbeda dan pembelajaran Fisika berorientasi model kooperatif Think Pair Square yang dirancang guru sudah berpusat pada siswa (student centered). Pembelajaran telah mampu menyebabkan siswa berperan aktif baik dalam bentuk mencatat, melakukan percobaan, bekerjasama, melakukan percobaan, berdiskusi, bertanya dan menanggapi pertanyaan, serta menyimpulkan. Dalam pembelajaran guru lebih berperan sebagai fasilitator yang membimbing dan mengarahkan siswa dalam belajar. Selama proses pembelajaran siswa diberikan kebebasan 
untuk menemukan konsep secara mandiri sehingga pembentukan konsepnya lebih bermakna. Dengan demikian aktivitas yang memungkinkan siswa dapat membangun sendiri pengetahuannya. Menurut Simamora (2011), aktivitas belajar yang tinggi dapat meningkatkan hasil belajar siswa. Keefektifan perangkat pembelajaran melalui implementasi dengan tiga replikasi di kelas $\mathrm{XA}, \mathrm{XB}, \mathrm{XC}$ dilihat dari:

Tes ini dilakukan untuk mengetahui penguasaan konsep siswa terhadap konsep-konsep yang diberikan selama pembelajaran. Tes hasil belajar yang digunakan adalah berupa tes pilihan ganda dengan 20 butir soal meliputi tes pengetahuan (kognitif). Tes dilakukan dua kali yakni sebelum (pretest) dan sesudah (postest) pembelajaran. Hasil analisis nilai evaluasi belajar yang diperoleh siswa setelah mengikuti pembelajaran menggunakan model pembelajaran Think Pair Square. Berdasarkan hasil perolehan data untuk kelas X-A setelah dilaksanakan pembelajaran dengan menggunakan model kooperatif Think Pair Square dengan menggunakan Buku Ajar Siswa (BAS) dan Lembar Kegiatan Siswa (LKS) yang telah dikembangkan nilai rata-rata kelas sebesar 81.55 , untuk kelas X-B diperoleh nilai rata-rata ketuntasan kelas sebesar 82.61, dan untuk kelas X-C diperoleh nilai ratarata ketuntasan kelas sebesar 82.14. Keberhasilan siswa dalam menuntaskan pembelajaran disebabkan oleh beberapa hal, yaitu: (1) ketersedian perangkat pembelajaran utama, yang meliputi: LKS, Buku Ajar Siswa, dan lembar penilaian yang baik, hal ini didukung oleh hasil telaah/validasi perangkat pembelajaran tersebut yang memperoleh kategori baik dan reliabel; (2) kemudahan guru dalam pelaksanaan pembelajaran sehingga pembelajaran dapat berlangsung dengan baik; (3) keterlibatan siswa secara aktif dalam pembelajaran. Beradasarkan data aktivitas siswa, didapat bahwa aktivitas siswa yang dominan adalah melakukan percobaan, bekerja sama antar kelompok, bertanya, menyampaikan pendapat serta menanggapi dan menghargai pendapat teman/kelompok. Aktivitas tersebut menunjukkan bahwa kegiatan pembelajaran berpusat pada siswa.

Pembelajaran yang demikian memungkinkan siswa secara aktif membangun pengetahuannya sendiri, guru hanya berindak sebagai fasilitator. Menurut Piaget keterlibatan siswa secara aktif dalam pembelajaran memudahkan mereka mengasimilasi dan mengakomodasi informasi baru sehingga siswa mudah memahami fakta yang ada dalam pengalaman tersebut. Lebih lanjut, Vygotsky dalam Nur (1998) menyatakan bahwa perkembangan dan pembelajaran terjadi dalam konteks sosial sehingga dalam pembelajaran hendaknya siswa diberikan kesempatan terlibat secara aktif dengan komunitas sosialnya, melalui interaksi tersebut siswa akan membangun pengetahuannya dengan teman sebaya yang berada pada zona perkembangan terdekat (zone of proximal development); (4) Respon positif siswa, yaitu siswa menyatakan bahwa materi ajar, Buku Ajar Siswa, LKS dan suasana belajar termasuk menarik dan baru, siswa berminat dengan metode pembelajaran yang diterapkan, siswa merasa terbantu dalam menggali dan mengolah informasi secara efektif, efisien, kreatif, dan siswa juga meras mudah dalam menjawab butir soal.

Berdasarkan teori motivasi, respon positif siswa sangat penting baik motivasi intrinstik yang berupa materi ajar, Buku Ajar Siswa, LKS, suasana belajar maupun motivasi ekstrinsik. Berdasarkan hasil data yang diperoleh terdapat 5 siswa yang mendapatkan nilai kurang dari 70 yakni kelas X-A terdapat 2 orang siswa yang tidak/belum tuntas, kelas X-B terdapat 1 orang siswa yang tidak/belum tuntas dan kelas X-C terdapat 2 orang siswa yang tidak/belum tuntas. Siswa yang belum tuntas ini disebabkan karena kurang terlibat aktif dalam pembelajaran sehingga respon terhadap pembelajaran khususnya pada pembelajaran Fisika kurang/rendah, kesulitan dalam belajar karena tingkat kemampuan nya rendah, hal ini terlihat dari wawancara dan daftar nilai yang diberikan oleh guru Fisika. Oleh karena itu siswa yang tidak tuntas ini akan mendapatkan remidial sampai menperoleh nilai yang sesuai dengan nilai kriteria minumum ketuntasan nya yakni $>70$.

Hasil ketuntasan indikator pada saat pretest dan postest yang dapat diuraikan secara singkat bahwa untuk tes pengetahuan (kognitif) saat pretest indikator yang tuntas adalah $0 \%$ dan pada saat posttest menunjukkan bahwa dari 20 tuntas. Berdasarkan Tabel 4.30 , soal THB yang terdiri dari 20 butir soal menunjukkan bahwa butir soal yang dibuat memiliki sensitivitas baik dan peka. Pada penelitian ini diperoleh nilai sensitivitas butir soal antara $0,33-0,58$. Nilai sensitivitas $\geq 0,30$ berarti soal peka terhadap efek pembelajaran menurut Aiken dalam Samsuri (2009), sehingga butir soal yang digunakan pada penelitian dapat dinyatakan peka terhadap efek pembelajaran.

Berdasarkan tes pengetahuan hasil belajar siswa sebelum dan sesudah pembelajaran dengan menggunakan pembelajaran kooperatif Think Pair Square didapatkan bahwa peningkatan skor penguasaan pengetahuan adalah bersifat signifikan dimana jawaban benar siswa pada posttest mengalami peningkatan. Hal ini membuktikan bahwa proses pembelajaran terlaksana dengan baik. Sementara itu berdasarkan hasil perhitungan skor peningkatan (n-gain score) diperoelah skor peningkatan untuk kelas X-A sebesar 0.60, pada kelas X-B sebesar 0.64 dan pada kelas X-C sebesar 0.62 sehingga dapat dinyatakan bahwa skor peningkatan rata-rata seluruh kelas tergolong sedang karena memiliki skor 0,62 atau $62 \%$ (Savinainen \& Scoot 2002). Sesuai dengan teori scaffolding oleh Vygotsky, 
siswa belajar melalui interaksi dengan orang dewasa dan teman sebaya yang lebih mampu. Dengan cara ini pendekatan yang digunakan oleh teman sebaya, maka tugas kelompok lebih berhasil. Artinya bahwa siswa tidak terlepas dari peran guru dalam memotivasi siswa sehingga tercipta lingkungan belajar yang efektif. Hal ini menunjukkan bahwa pembelajaran model kooperatif Think Pair Square yang diterapkan dalam pembelajaran Fisika materi kalor dapat meningkatkan penguasaan konsep siswa secara signifikan.

a. Siswa merespon sangat positif hasil pengembangan perangkat dan pelaksanaan pembelajaran dengan model kooperatif tipe Think Pair Square. Hal tersebut dapat dilihat dari hasil analisis data respon siswa sebanyak $87.04 \%$ siswa merespon dengan kriteria sangat kuat.

b. Penerapan sikap ilmiah yang meliputi karakter dan keterampilan sosial karena didasari oleh salah satu tujuan pendidikan nasional yang ada dalam Kurikulum 2013 bertujuan untuk mempersiapkan manusia Indonesia agar memiliki kemampuan hidup sebagai pribadi dan warga negara yang beriman, produktif, kreatif, inovatif, dan afektif serta mampu berkontribusi pada kehidupan bermasyarakat, berbangsa, bernegara, dan peradaban dunia. Melalui penanaman sikap karakter dan keterampilan sosial dalam kegiatan pembelajaran di sekolah, bertujuan agar dapat mengaplikasikan sikap ilmiah tersebut dalam kehidupan sehari-hari saat berinteraksi dengan lingkungannya. Menurut Simamora (2012) dengan pendidikan karakter dan keterampilan sosial yang diterapkan secara sistematis dan berkelanjutan, seorang anak akan cerdas tingkat emosinya. Kecerdasan emosi ini adalah bekal penting dalam mempersiapkan diri anak dalam kehidupan di masa yang akan datang. Keterampilan sosial siswa diamati oleh dua orang pengamat terlihat pada gambar 6 .

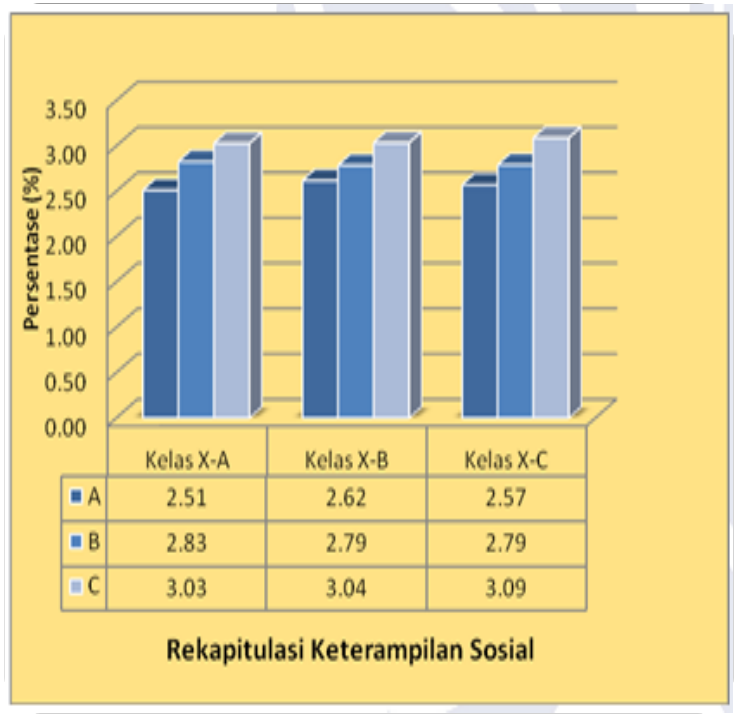

Gambar 6. Keterampilan sosial siswa
Hasil pengamatan keterampilan sosial, yakni menyumbang ide/pendapat, menghargai pendapat teman, dan bekerjasama dapat dinyatakan bahwa hasil dari pengamatan secara umum mengalami peningkatan dari pertemuan pertama hingga ketiga dengan kategori B yakni memuaskan. Skor rata-rata keterampilan sosial dalam menyumbang ide/pendapat memperoleh skor 2,79 atau berada pada kategori mengalami kemajuan (baik), skor terendah memperoleh skor 2,00 (kurang baik).

Hal ini dapat dipahami karena siswa belum terlalu aktif, masih ada rasa malu, sungkan atau takut dalam menyampaikan ide/pendapat serta pertanyaan siswa yang didiskusikan juga masih terbatas. Keterampilan sosial dalam menghargai pendapat teman secara umum mengalami peningkatan dengan skor 2.81 atau berada pada kategori memuaskan (baik), hal ini menunjukkan pembelajaran semakin tertib, dan siswa dapat menghargai pendapat teman. Keterampilan sosial dalam hal bekerjasama juga mengalami peningkatan skor ratarata sebesar 2.82. Hal ini berarti siswa mampu berkolaborasi, saling bantu membantu dalam menyelesaikan permasalahan yang diajukan dalam pembelajaran, namun demikian masih ditemukan beberapa siswa yang memperoleh skor 2,00 (kurang baik) pada pertemuan pertama dapat dilihat dalam lampiran.

Hal ini disebabkan karena siswa tersebut kurang berpartisipasi aktif dalam menyelesaikan tugas, tetapi pada pertemuan kedua dan ketiga sudah mengalami peningkatan bahkan pada pertemuan ketiga seluruh siswa menunjukkan perilaku yang sangat baik. Hal-hal tersebut sesuai dengan pengamatan aktivitas siswa bahwa aktivitas siswa yang tidak relevan mengalami penurunan. Hal ini menunjukkan secara keseluruhan bahwa keterampilan sosial tercapai. Secara umum perilaku berkarakter dan keterampilan sosial berada pada kategori memuaskan, bahkan pada pertemuan terakhir seluruh siswa berada dalam ketegori sangat baik, hal ini disebabkan oleh beberapa hal, yaitu: (1) berdasarkan data keterlaksanaan pembelajaran diperoleh hasil bahwa umumnya sintaks pembelajaran dapat terlaksana dengan baik. Pada sintaks tersebut keterampilan sosial diskenariokan sehingga guru selalu mengingatkan untuk melaksanakan kegiatan percobaa/eksperimen dengan menerapkan perilaku keterampilan sosial; (2) berdasarkan data pada aktivitas siswa didapatkan hasil bahwa siswa terlibat aktif dalam pembelajaran dan menerapkan perilaku sosial seperti: menyampaikan pendapat, menghargai pendapat teman dan bekerjasama; (3) berdasarkan data respon siswa diperoleh hasil bahwa siswa sangat terbantu dalam mengembangan kamampuan berkomunikasi dan bekerjasama. Model pembelajaran kooperatif Think Pair Square menunjukkan efektif untuk 
mengembangkan keterampilan sosial, hal ini sesuai dengan yang diungkapkan oleh Arends (2012) bahwa pembelajaran kooperatif yang dikembangkan untuk mencapai setidak-tidaknya 3 tujuan instruksional penting, yaitu: kemampuan akademik, penerimaan terhadap individu, dan pengembangan keterampilan sosial. Sementara itu menurut Vygotsky, interaksi sosial siswa dengan memperbesar tingkat perkembangan potensial siswa dan salah satu cara untuk melatih siswa agar terampil berkomunikasi adalah dengan melakukan pengamatan baik melalui indera penglihatan, pendengaran, peraba yang merupakan salah satu keterampilan proses sains; mempresentasikan hasil dari pengamatan, diskusi maupun kerja kelompok; menyatakan ide/gagasan; menanggapi pendapat/menjawab pertanyaan; mengajukan pertanyaan. (Nur, 2008). Menurut Nufus (2011) model pembelajaran kooperatif, efektif untuk mengembangan keterampilan sosial siswa yang tidak dapat ditemukan pada pembelajaran konvensional.

Berdasarkan hasil di atas dapat disimpulkan bahwa perangkat pembelajaran model kooperatif tipe Think Pair Square yang telah dikembangkan efektif untuk meningkatkan keterampilan sosial dan ketuntasan belajar siswa SMA

\section{KESIMPULAN}

Berdasarkan analisis, pembahasan dan temuan hasil penelitian dapat disimpulkan bahwa perangkat pembelajaran Fisika berorientasi model pembelajaran kooperatif Think Pair Square yang dikembangkan layak, praktis, dan efektif untuk meningkatkan keterampilan sosial dan ketuntasan belajar siswa. Berdasarkan penelitian yang telah dilakukan dan hasil yang didapat, disarankan beberapa hal sebagai berikut:

1. Pada proses pembelajaran berorientasi model pembelajaran kooperatif Think Pair Square, guru harus mengatur waktu seefektif mungkin, agar pembelajaran dapat berlangsung sesuai dengan tujuan yang telah ditentukan.

Penelitian ini perlu dikembangkan lebih lanjut untuk pokok bahasan lain guna meningkatkan keterampilan sosial dan hasil belajar Fisika.

\section{REFERENSI}

Afrizon, Renol., Ratnawulan,.dan Fauzi, Ahmad. (2012). "Peningkatan perilaku berkarakter dan ketrampilan berpikir kritis siswa kelas $\mathrm{x}$ mtsn model pada mata pelajaran ipa-fisika menggunakan model problem based instruction". Jurnal Penelitian Pembelajaran Fisika. ISSN2252-3014.

Aiken, L. (1997). Psycological testing and assesment, Ninth Edition. New York: McGraw Hill Company.
Aisah, Siti. (2013). "Penggunaan model pembelajaran cooperative learning tipe think pair square berbantuan kartu soal untuk meningkatkan aktivitas belajar siswa kelas VII B SMP Negeri 5 Purworejo". e-Journal Radiasi. Vol.3 No.1. Tersedia

Amri, Sofan. (2013). Pengembangan \& model pembelajaran dalam kurikulum 2013. Jakarta : Prestasi Pustaka Publisher.

Arends, R. (2008). Learning to teach. New York : Mc.Graw Hill Companies Inc.

Arikunto, S. (2002). Dasar-dasar evaluasi pendidikan. Jakarta: Bumi Aksara.

Budiriyanto. (2013). Pengembangan perangkat pembelajaran kooperatif tipe numbered heads together (nht) untuk meningkatkan hasil belajar siswa pada materi kalor (Tesis Magister Pendidikan Tidak Dipublikasikan) Pps Universitas Negeri Surabaya.

Depdiknas. (2006). Peraturan menteri pendidikan nasional republik indonesia no.22 tahun 2006 tentang standar isi untuk satuan pendidikan dasar dan menengah. Jakarta: Dirjen Dikdasmen.

Dimyati dan Moedjiono. (2002). Belajar \& pembelajaran. Jakarta : PT. Asdi Maha Satya.

Douglas C. Ginacoli. (1999). Fsika edisi kelima terjemahan. Jakarta : Erlangga.

Felder, Richard M., and Brent, Rebecca. (2007). "Cooperative learning". Internasional Journal. Downloaded by Curtin Univ Tech on 28 Desember 2013. (Online).

G.D. Borich. (1994). Observation skills for effective teaching. New York : McMilan Publishing Company.

Gronlund, N.T. (1985). Castructing achievment test, Fifth Edition. Newyork: Prentice Hall Inc.

Hairida. (2011). “Assesmen otentik: menghadapi era globalisasi (Menjawab tantangan internal dan eksternal pendidikan)". Jurnal Visi Ilmu Pendidikan. Vol. 5 No.2, pp. 417-431.

Hake. (1999). Analyzing change/gain scores. (Online). Tersedia http://www. physicsindiana.edu/sdi/Analyzing-Change-Gain. pdf. Diakses 15 Desember 2013.

Halliday, D., Renick, R. \& Walker, J. (1985). Fundamental of physics. Jhon Wiley dan Sons Inc.

Hamalik,Oemar. (2003). Proses belajar mengajar. Bandung : Bumi Aksara.

Hartati, S. dan Sudarisman,S. (2011). "Perbedaan pengaruh pembelajaran kooperatif tipe think pair share dan number head together terhadap prestasi belajar biologi peserta didik kelas VIII di SMP negeri 12 kota Magelang".(Online).

Hartati. (2014). Pengembangan perangkat pembelajaran kimia berbasis pendekatan 
keterampilan proses untuk meningkatkan penguasaan konsep dan keterampilan berpikir kritis siswa pada materi pokok koloid di SMA (Tesis Magister Pendidikan Tidak dipublikasikan). Pasca Sarjana Unesa.

Hasanah, Retno. (2001). Fisika Dasar I (Seri Thermofisika). Surabaya: Unesa University Press.

Husna. Ikhsan, M. dan Fatimah, Siti. (2013). "Peningkatan kemampuan pemecahan masalah dan komunikasi matematis siswa sekolah menengah pertama melalui metode pembelajaran kooperatif think pair share". Jurnal Peluang (Onlie). Vol. 1 No. 2 ISSN: 2302-5158. pp. 81-92

Ibrahim, M. (2002). Pengembangan perangkat pembelajaran (modul pelatihan terintegrasi berbasis kompetensi guru mata pelajaran biologi SLTP). Jakarta : Depdiknas.

Ibrahim, M. (2005a). Pembalajaran kooperatif. UNESA. Surabaya : University Press.

Ibrahim, M. (2005b). Assesment berkelanjutan, konsep dasar tahapan pengebangsa dan contoh. Surabaya: Unesa University Press.

Isjoni. (2009). Cooperative learning efektifitas pembelajaran kelompok. Bandung

Johnson, D. W. and Johnson, R. T. (2002). Meaningful assesment. a manageable and cooperative process. Boston: Allyn \& Bacon.

Junanto, T. (2010). "Pengaruh pembelajaran kooperatif tipe student teams achievement divisions (stad) dan think pair share terhadap prestasi belajar ditinjau dari sikap ilmiah". Jurnal Pendidikan Matematika dan IPA. Online).

Kardi, S. (2002). Pengembangan tes hasil belajar. Surabaya: University Press.

Kardi, S. (2008). Tujuan pembelajaran, perumusan dan penggunaannya. Surabaya: Program Pascasarjana Universitas Negeri Surabaya.

Kemendikbud. (2012). Pedoman penulisan tesis dan disertasi. Program PascaSarjana Unesa: Surabaya.

Kemendikbud. (2013). Standar kompetensi lulusan, kompetensi inti, dan kompetensi dasar pada kurikulum 2013. Jakarta

Kemp, Jerold E. (1994). Designing effective instruction. New York. Mc Milan College Publishing Company.

Kusuma, Febrian Widya., Aisyah, Mimin Nur. (2013). "Implementasi model pembelajaran kooperatif think pair share untuk meningkatkan aktivitas belajar akuntansi siswa kelas XI SMA Negeri 2 Wonosari”. Jurnal Pendidikan Akuntansi Indonesia (Online). Vol. X No. 2.

Lie, Anita. (2008). Cooperative Learning. Jakarta : PT. Grasindo.

Nufus, Nurhayati. (2013). Pengembangan perangkat pembelajaran model kooperatif think pair share untuk melatihkan keterampilan proses sains pada materi bunyi kelas VIII ( Tesis Magister Pendidikan Tidak Dipublikasikan). Pps Universitas Negeri Surabaya.

Nur, Mohamad. (2008). Teori-teori perkembangan. Surabaya: Pusat Sains dan Matematika Sekolah. Universitas Negeri Surabaya.

Nur, Mohamad. (2011). Model pembelajar kooperatif. Surabaya : Pusat Sains dan Matematika Sekolah. Universitas Negeri Surabaya.

Nurkhasanah, Lina. (2013). "Efektivitas pembelajaran kooperatif tipe two stay two stray (tpst) dan think pair square (tpsq) melalui pemanfaatan peta konsep terhadap prestasi belajar siswa pada pokok bahasan sistem koloid kelas XI SMAN 4 Magelang tahun ajaran 2011/2012”. Jurnal Pendidikan Kimia (JPK).ISSN 2337-9995 Vo.2 No.2 Tahun 2013.

Permendikbud RI Nomor 65. (2013). Standar proses pendidikan dasar dan menengah. Jakarta: Kementrian Pendidikan Nasional.

Permendiknas Nomor 22. (2006). Standar kompetensi dan kompetensi dasar. Jakarta: Kementrian Pendidikan Nasional.

Prabowo, (2011). Metodologi penelitian (sains dan pendidikan sains). Surabaya: Unesa University Press.

Sanjaya, Wina. (2007). Strategi pembelajaran berorientasi standar proses pendidikan. Jakarta : Kencana.

Sears and Zamansky. (2002). Fisika universitas jilid I. Jakarta: Erlangga

Setiawan, Dwi Cahya. (2013). "Penerapan model pembelajaran kooperatif tipe think pair square dengan menggunakan lembar kerja siswa (lks) berbasis pendidikan matematika realistic (PMR) pada siswa kelas VIII SMP Al- Alawiyah Kalikajar”. Jurnal Pendidikan Matematika. ISSN 2337-4411. Vo. 5 No.1.

Siburian, Ellyst R. (2012). Pengaruh penerapan model pembelajaran berdasakan masalah terhadap penguasaan konsep fisika fluida statis dan kemampuan berpikir kritis siswa (Tesis Magister Pendidikan Tidak Dipublikasikan). Pps Universitas Surabaya.

Simamora, A. (2012). Pengembangan perangkat pembelajaran fisika berorientasi model pembelajaran beradsarkan masalah dalam meningkatkan keterampilan berpikir, berperilaku dan keterampilan sosial siswa (Tesis Magister Pendidikan Tidak Dipublikasikan). Pps Universitas Surabaya.

Sobhani, A. (2012). "The impact of cooperative learning on oral proficiency". Journal of sosial sciences (Online). 
Sudarwanto. (2013). Hakekat pembelajaran fisika. (Online). Tersedia

Sutrisno, (1983). Fisika dasar: listrik magnet dan termofisika. Bandung: Institut Teknologi Bandung

Tan, Gabriel; Gallo, Patrick B; Jacobs, George M and Lee, Christine Kim-Eng. (1999). "Using cooperative learning to intergrate thinking and information technology in a content-based writing lesson". The Internet TESL Journal. Vol. V, No.8.

Tanal, Zafer., dan Erol, Mustafa. (2008). "Effect of cooperative learning on instructing magnetism: analysis of an experimented teaching sequences". Journal Physics Education.

Tresnayanti, Ni Made Dwi; Lasmawan, I Wayan; dan Marhaeni, A.A.I.N. (2013). "Pengaruh model pembelajaran think pair square terhadap motivasi berprestasi dan prestasi belajar IPS siswa kelas VII
SMP Negeri 3 Singaraja".e-Jornal Program Pascasarjana Universitas Pendidikan Ganesha Jurusan Pendidikan Dasar. Vol. 3 Tahun 2013.

Widiastuti, Sussi. (2013). Implementasi peta konsep menggunakan model pembelajaran kooperatif (TPS) sebagai cognitive diagnostic assesment (CDA). Jurnal Pendidikan Sains Pascasarjana Universitas Negeri Surabaya, ISSN: 2088-177. Vol. 2 No. 1, pp. 36-41

Young, Hugh D \& Freedman, Roger A. (2002). Fisika universitas edisi kesepuluh jilid I. Jakarta: Erlangga

Zulfatni. (2004). Pengembangan perangkat pembelajaran model diskusi tps bahan hormon manusia diimplementasikan pada SMP (Tesis Magister Pendidikan tidak dipublikasikan). Pasca Sarjana Unesa. 